\title{
Community, Social Capital and Development Policy in Code Riverbanks
}

\author{
Cahyo Seftyono \\ Faculty of Social Sciences \\ Universitas Negeri Semarang \\ Semarang, Indonesia \\ cahyo.seftyono@mail.unnes.ac.id
}

\author{
Rina Noviyanti \\ Masoek Kampoeng Indonesia \\ Depok, Indonesia
}

\begin{abstract}
Social capital has the important role in common policy and developmental issue. Development requires public involvement and government initiative with two ways policy communication based on "trust" and "social network". In Kali Code riverbanks- Yogyakarta development, which is geographically disasterprone area, the development ideas dialectic has to follow more intensely. This purposive sampling method was done by interviewing Yogyakarta Municipality, community activists, and environment activists. The finding is that the dilemma in disaster-prone area development course proposed by the government, caused people boost their development ideas with social capital approach. So some main programs which change Kali Code Riverbanks arise, from disaster-prone to become relatively safer and has economics values.

Keywords-Social Capital, Community and Development, Disaster Prone-area; Code Riverbanks-Yogyakarta
\end{abstract}

\section{INTRODUCTION}

In 2015, an activist of Pamerti Code Boyong, Totok Pratopo, the successor of YB Mangun Wijaya received Kalpataru Award from President Joko Widodo. Mangun Wijaya initiated this riverbank to be descent dwelling with his architectural concept. There are some changes follows the current condition. Totok Pratopo's ability to encourage the people in the area of social modal is remarkable. Both personal approach and relation that actively built through ITC (Information Technology Communication) based communication.

The development of Kali Code riverbanks is a dynamic process. How the government and the people unite their view is a challenge itself [1] [2]. However, riverbank is an area that is supposed to be free from residents, especially with the floods, cold lava and deluge due to the downpour, during 2010-2015. This area definitely needs better structuring [3]. Because of that, Yogyakarta municipality and province government together with the people and NGOs collaborate to establish Kali Code riverbank which could fulfill people's need: safe and ecotourism-based.

River development program in Yogyakarta had started from KIP (Kampung Improvement Program) then developed into more practical patterns, known as Tridaya Program: Physical Development (Bina Fisik), Environmental Development (Bina Lingkungan), and Social Economic Development (Bina Sosial Ekonomi). It has started since 1990es. It gradually changes the mindset of Code residents, who formerly thought that river is the back part of the house where they throw waste away, now they make the river as the front part. Specifically in 1999-2000 Kampung Action Plan is also developed in Code area and Cokrodiningratan. This program works on society based development. Meanwhile, institutionally there is Prokasih that annually held by Ecology Bureau (Balai Lingkungan Hidup). Some local and international non profit organizations refer Kali Code as riverbank development reference [4] Here could be seen that despite the ups and downs of government support in Kali Code riverbank, the community and NGO could balance that development activity by 
strengthening social politics networks, so the development process goes on.

Kali Code riverbank development research could be divided into some clusters: community and social modal, ITC optimization and social modal, and disaster-prone area development. The first cluster, regarding to the community and social modal, basically development in Kali Code has got model change from the first activist to the second. Firstly, Kali Code riverbank development was based on architecture with the influence of RM Wijaya. Secondly, now, Kali Code riverbank development coordinated by Totok Pratopo. Totok Pratopo acts as a central coordinator in Kali Code riverbank development. Totok maximizes the existing social modal potency in order to build network both internal within the society through Pamerti Code Community and Code Boyong Community together with other institutions which concern on the development of that area. Because of that, the flow of the development tends to be combination of topdown from government and bottom-up from people's inputs [5]. Development that has this two ways combination indirectly gives different realm in people relation of social politics. When riverbank was previously identical with negative stuff, including Kali Code riverbank, now that image starts changing [6]. Furthermore in some recent years, some awards received individually by Totok Pratopo, Pamerti Code Community as river-concerned community, or Kali Code riverbank as destination for local or international academician and researcher.

The second cluster is how ITC affects the solidity of social modal in the society. So far, social modal built by physical relation, and along with the advance in information technology and communication, social modal could be strengthened more effective and efficiently. Social modal indicators like honesty, take and give relationship, prioritizing public interest could be built by more intense communication and not limited by space and time, as done through social media and website. This is inline with what Zuniga [7] said that the easy of communication will increase the bonding between citizens as well as increase political participation. Once each individual understands the position in the society, they will voluntarily fill their role and right. Political participation is not merely about election, it is also about caring and willingness to fight for development vision that they want. Political participation is also not limited to off-line participation, but also ITCbased participation. When the awareness of being society goes along with the increase of political participation, social modal bonding in a society will keep strongly bonded.

The third cluster is positive and negative dilemma of disaster-prone area development. It couldn't be resisted that in development concept that Cost and Benefit Analysis is crucial, due to its limited budget and its limited time in doing the programs expected by government. In this concept, disaster-prone area development also referred to values expected from that development discourse [2]. Moreover, Kull [8] mentioned considerations in deciding development in disaster-prone area usually related to economy, environment, and the future of the people around the area. In this case, development often addresses the anticipation of the possible disaster. This is possibly done with economic, ecological, and social consideration, hoping that the development won't take bigger cost for the next disaster.

\section{METHOD OF RESEARCH}

This research is done with case study method. This method is chosen due to the potency to find uniqueness in the finding of the research to analyze further [9] [10]. Research with case study method enables the use of analyzed cases to get the pattern to be used for the on-going research. In this case, studies about society, politics, and environment outside Kali Code riverbank is also used to explain findings from interview and document related to Kali Code riverbank society.

On the other hand, to get primary data in-depth interview with Ritchie et.al [11] approach is used, which the research uses purposive non- probability sampling to collect deeper information which is not legal and formal combined with document and interview from various sources. Due to limited time and budget, only possible interviewee will be interviewed. Nevertheless, to justify the argumentation, each 
source's related statement in mass media will be used as the important secondary data to develop analysis. This is possible because in this method informant known as "symbolic represent" of the information in field. They are deemed to be knowledgeable and rich of information and various perspectives to explain the matter. The informants are classified into three groups: government, people, and NGO. Information from these sources collected by direct interview and social media interactive discussion: WhatsApp, Facebook and Website.

\section{FINDING AND DISCUSSION}

Community which concerns on Kali Code riverbank development started from YB. Mangunwijaya who changed community life style which formerly use the river as their disposal to become conservation area. Waterfront concept [4] changes people behavior to be more environment-friendly. Additionally, decenter architectural concept causes Kali Code riverbank enables people to fix human and river relation. Development made by YB Mangunwijaya changes the perception of disaster-prone area [12] which means natural disaster and social conflict, to become relatively safe area and less conflict. This is due to good development of the riverbank, as well as empowering social relation within society to be more interactive.

The next people consolidation phase is Pamerti Code initiated by Totok Pratopo and was founded in 2008 by Herry Zudianto, the mayor of Yogyakarta. Pamerti Code activity is very diverse, cleaning up the river, utilize the river for competitions venue, and for culture festival Merti Code which aimed to comprehend the importance of river for society life. Through Pamerti Code, riverbank especially at Gondolayu and Jetisharjo, prepared as eco-tourism area. Other than approaching institutionally to academicians and government, Totok Pratopo also strengthens existing networking through informal approach, like religious and cultural activity, Totok Pratopo and Pamerti Code get support from various religious institutions.

Pamerti Code gets stronger and more popular, then inspires and becomes movement reference to other communities. Hence, now there are communities with wider membership from Boyong Utara Community to Boyong Selatan Community. The aim is to broaden Kali Code riverbank development idea to make it becomes eco-tourism area which is ecologically and economically impactful for the people around. Interesting part of Boyong Code Community is the change of communication, which formerly used Handy Talky, now they optimize social media, which makes it more effective and efficient.

Communication plays significant role in community bonding, what activists of Code Boyong Community in Kali Code riverbank do for instance. The dynamic of people-government relation in riverbank development, then society creates their own social networks. Nevertheless, this is not effective enough, considering the big budget needed. Hence, in the beginning of more formal river community, Yogyakarta municipality and Daerah Istimewa Yogyakarta government facilitate the formation of communication group cadres in each RT/RW (group of houses, smaller than village).

These communication groups will fast connect people and the government when development ideas or disaster threat emerge. As stated by Grindle [13], what has been done by the government during 'reformation era' is by directly getting in touch with the people in order to know the subject of its policy for real. Through this method, government could give what the people want and could 'serve' the people need. With the existence of more structured groups and communication forums, the implementation process of the development policy run by government is no longer an authoritarian mechanism, but rather there are people influence, although as mentioned previously, the influence tends to be fluctuated [4]. Government's view towards people participation tends to be independent support and local people contribution, not their (the people) involvement. When government is stuck, then Code Boyong Community will invite other communities which are wider to be together make eco-tourism Kali Code comes true.

The community will be strengthened by communication groups and getting more effective with the function optimization of ITC, especially WhatsApp. The communities in Kali 
Code riverbank, from Boyong Atas Community, Peduli Code Community, Pamerti Code, Code Bantul Community, Boyong Selatan Community, Dewo Bronto Community, and Boyong Muda Community, together with government, NGOs, and academicians are easily connected by regularly updating the latest information by social media. Thus they could support each other's program. This is how the potencies of each community could be triggered, as well as inspires other communities. It is also a platform to build their trust by minimizing the conflict of interest, because all information is open for all communities [14]. Eventually, social bonding gets stronger.

As a disaster-prone area Kali Code riverbank development is seen as dilemmatic by the government. Therefore, the development flow tends to be given to the society through the communities, which later have partnership with NGOs. Limited budget and various development priorities cause Kali Code being not prioritized by municipality and province government [4]. Some years ago this area used to get some attention in term of development, as fulfilling basic need of the people and as eco-tourism prototype.

Judging from the existing development process, known that development process refers to primary needs to tertiary. Primary means strengthening river boundary line as preventive action of flood, building public bathing, washing, and toilet facilities (MCK), revitalizing clean water resource, housing aspects, etc. All aspect related to housing is definitely crucial in disaster [15]. For this category, development in primary corridor has already run for long time and is still going on within the coordination of government and society. This is because those needs are human right of the citizens [16]. Regardless the pro and cons about disaster-prone area development, both government and communities agree to not ignore this thing. The people have to be able to live safely, out of the disaster, and getting their basic need fulfilled.

The second need of Kali Code riverbank development is to fulfill the secondary need, development and utilization of Kali Code riverbank area for social activities in the society. For social activity category, society uses Kali Code riverbank for informal education and meeting point to strengthen people solidity.

The last category is tertiary, where the activists build wider network to introduce Kali Code to domestic and international level. Other than cultural activities like annual Merti Code, the edge of the river has been well-managed which meant to be eco-tourism track with river trekking idea. Tertiary development could also be seen on rain receptacle and tourism village (kampong wisata), where there are many culinary vendors as supporting facility while enjoying the beauty of Kali Code.

\section{CONCLUSION}

Community has important role in development. Community doesn't only support their interest in order to mainstream bottom up policy, rather also as an alternative that has impact for public and the country. Kali Code with discourse efforts show how impactful the role of the community is.

This community regularly arrange meeting with the government and the people involve in order to "rebuild" the riverbank, as well as strengthening networks by website and more sophisticated communication media: WhatsApp, Facebook, Blog, Website, etc. The result is riverbank development that's been in rejected-accepted state by the government slowly shows its existence and achievement. The activists of river-concerned don't only get appreciation from government, through Kalpataru and so on, but Kali Code riverbank also becomes reference for river activist from all over the world.

Therefore, Pamerti Code community becomes the engine of this river-friendly awareness, be one of role models in strengthening institution capacity of NGO to society based policy. Pamerti Code comprehends that development in disaster-prone area like riverbank surely needs comprehensive approach, without violence that is so typical of eviction. Rather, it is about how they could collaborate with government and other development actors to maximize the potencies. So the area that formerly seen as dangerous, with the right development could be safe and comfortable to be 
dwelling for the people.

\section{ACKNOWLEDGMENT}

Some of this research is funded by the scheme of Fakultas Ilmu Sosial-Universitas Negeri Semarang Grant 2016. Muhammad Luthfi and Ustad Mangku Alam assist the field research, with the task to interview some of the respondents and to collect secondary data. Nevertheless, the authors are fully responsible of the content.

\section{REFERENCES}

[1] Darwis Khudori, 2002. Menuju Kampung Pemerdekaan, Yogyakarta: Yayasan Pondok Rakyat,.

[2] Cahyo Seftyono, 2010. Local Community in Valuing Ecosystem Services: Warga Kampung Code's Perspective on Kali Code Existence, Proceeding 1st Annual Indonesian Scholars in Taiwan. doi: 10.2139/ssrn.1763226.

[3] Mahditia Paramita, Totok Pratopo dan Harris Syarrif Usman. 2016. Geliat Masyarakat Kali Code: Nadi Jogja nan Istimewa, Yogyakarta: Hunian Rakyat Caritra

[4] Cahyo Seftyono, 2013. Dilema Implementasi Kebijakan Pembangunan Bantaran Kali Code-Yogyakarta, Yogyakarta: Tesis Departemen Politik dan Pemerintahan UGM.

[5] Cahyo Seftyono, 2012. Kali Code: From Merapi to Sustainable Society, Proceeding IcoSI. UMY-IIUM-TU Eindhoven.

[6] Cahyo Seftyono, 2012. Pembangunan Berbasis Waterfront dan Transformasi Konflik di Bantaran Sungai, Jurnal Sosial Politik-Universitas Gadjah Mada, Vol. 16 No. 1.

[7] Homero Gil De Zuniga, Nakwon Jung and Sebastian Valenzuela. 2012. Social Media Use for News and Individuals' Social Capital, Civic Engagement and Political Participation, Journal of ComputerMediated Communication, Vol.17, , pp. 319-336.
[8] Daniel Kull, Reinhard Mechler and Stefan Hochrainer-Stigler. 2013. Probabilistic Cost-benefit Analysis of Disaster Risk Management in a Development Context, Disasters, Vol. 37 No. 3, , pp. 374-400.

[9] R.K. Yin, 1994. Case Study Research: Design and Methods, vol. 5, Applied Social Research Methods Series, Thousand Oaks, California: Sage Publications.

[10] W. L. Neuman, 2006. .Social Research Methods: Qualitative and Quantitative Approaches. Boston: Pearson.

[11] Ritchie, J. and Lewis, J. (Eds.). 2003. Qualitative Research Practice: a guide for social science students and researchers. London: Sage,

[12] Jiuping $\mathrm{Xu}$, Ziqi Wang, Feng Shen, Chi Ouyang and Yan Tu. 2016. Natural Disaster and Social Conflict: A Systematic Literature Review, International Journal of Disaster Risk, Vol. 17, , pp. 38-48.

[13] Merilee S. Grindle, 2007. Good Enough Government Revisited, Development Policy Review, Vol. 25 No. 5, , pp. 553-574.

[14] Marleen Hysman and Volker Wulf. 2006. IT Support to Knowledge Sharing in Communities, Towards a Social Capital Analysis, Journal of Information Technology, Vol. 21 Issue 1, , pp. 40-51.

[15] Mary C. Camerio, 2014. Disaster Recovery and Community Renewal: Housing Approaches, Cityscape: A Journal of Policy Development and Research, Vol. 16 No. 2, pp. 51-68.

[16] Stroma Cole, 2014. Tourism and Water: From Stakeholders to Rights Holders, and What Tourism Businesses Need To Do, Journal of Sustainable Tourism, Vol. 22 No. 1, , pp. 89-106. 